\title{
Historical and Archival Documentation for Pioneer Park, Bexar County, San Antonio, Texas
}

I. Waynne Cox

Follow this and additional works at: https://scholarworks.sfasu.edu/ita

Part of the American Material Culture Commons, Archaeological Anthropology Commons, Environmental Studies Commons, Other American Studies Commons, Other Arts and Humanities Commons, Other History of Art, Architecture, and Archaeology Commons, and the United States History Commons

Tell us how this article helped you.

This Article is brought to you for free and open access by the Center for Regional Heritage Research at SFA ScholarWorks. It has been accepted for inclusion in Index of Texas Archaeology: Open Access Gray Literature from the Lone Star State by an authorized editor of SFA ScholarWorks. For more information, please contact cdsscholarworks@sfasu.edu. 


\section{Historical and Archival Documentation for Pioneer Park, Bexar County, San}

Antonio, Texas

\section{Creative Commons License}

\section{(c) (1) (8)}

This work is licensed under a Creative Commons Attribution-NonCommercial 4.0 International License 
HISTORICAL AND ARCHIVAL DOCUMENTATION FOR PIONEER PARK, BEXAR COUNTY, SAN ANTONIO, TEXAS

I. Waynne Cox

Center for Archaeological Research The University of Texas at San Antonio ${ }^{\circledR}$

Archaeological Survey Report, No. 196 
A list of publications offered by the Center for Archaeological Research can be obtained by sending $\$ 1.00$ to the Center for Archaeological Research, The University of Texas at San Antonio, San Antonio, Texas $78285-0658$. 


\begin{abstract}
An archival search was conducted to determine the impact of planned modifications to Pioneer Park, located along the east bank of the San Antonio River, near the intersection of Hildebrand Avenue and Broadway in north San Antonio. It was determined that the planned construction would have no impact on archaeological resources. However, if further alterations to the park are planned, monitoring should be considered.
\end{abstract}




\section{TABLE OF CONTENTS}

ABSTRACT $\ldots \ldots \ldots \ldots \ldots \ldots \ldots \ldots \ldots \ldots \ldots \ldots \ldots \ldots \ldots \ldots \ldots$

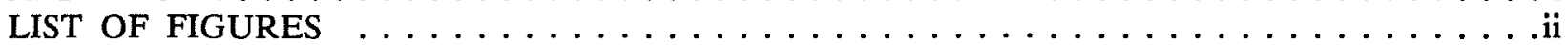

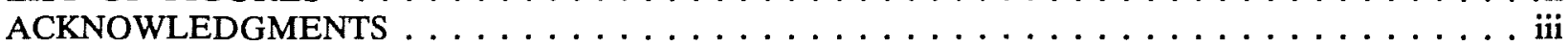

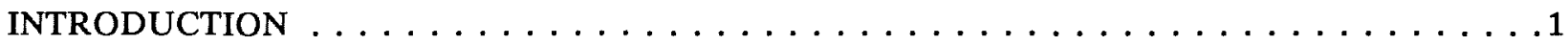

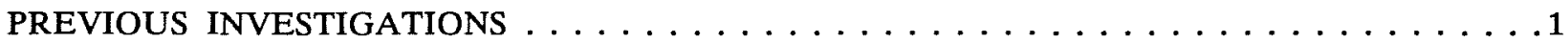

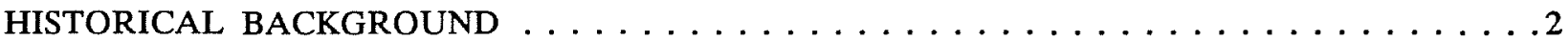

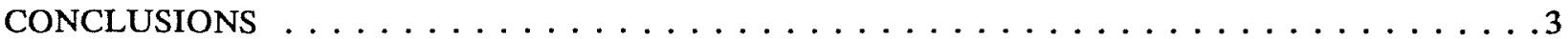

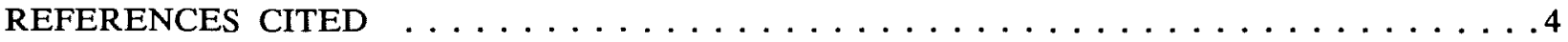

\section{LIST OF FIGURES}

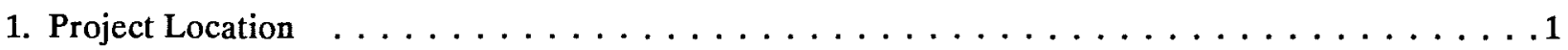

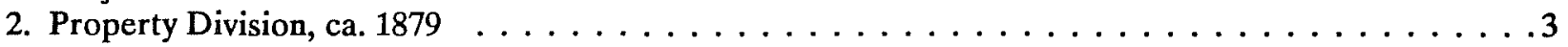




\section{ACKNOWLEDGMENTS}

The author would like to thank Mr. Gary Thompson and Mr. Pete Campos of Southwestern Bell Telephone for their cooperation and patience. Also, this research would not have been possible without the assistance of the Bexar County archivist, the staff of the Daughters of the Republic of Texas Research Library, the main San Antonio public library, and the library of the San Antonio Conservation Society. 



\section{INTRODUCTION}

In February 1990, the Center for Archaeological Research (CAR), The University of Texas at San Antonio (UTSA), entered into a contract with Southwestern Bell Telephone to provide a historical and archival background assessment for Pioneer Park, located on the east bank of the San Antonio River at Hildebrand Avenue (Fig. 1). The background research was required prior to development of the park site.

\section{PREVIOUS INVESTIGATIONS}

Although no previous archaeological investigations have been conducted within the park site, there have been prehistoric occupations and burials reported for the general area. An avocational archaeologist, C. D. Orchard, was recording sites within the Olmos Basin as early as the 1920s (Orchard and Campbell 1954; Orchard 1966, 1974). In 1974, Anne Fox conducted a survey from the Olmos Dam to Hildebrand Avenue where both historic and prehistoric sites were recorded on the lands owned by the Sisters of Charity of the Incarnate Word (Fox 1975). In 1976, an archaeological and historical survey was conducted within the boundaries of Brackenridge Park to the west and south of Pioneer Park (Katz and Fox 1979). In 1980, excavations at site 41 BX 1, north of Olmos Dam, documented a Late Archaic cemetery and Early to Late Transitional Archaic occupations, spanning a period from 1680 B.C. to A.D. 260 (Lukowski 1988). A summary of the archaeology and early history of the head of the San Antonio River is provided in a report by Stothert (1989).

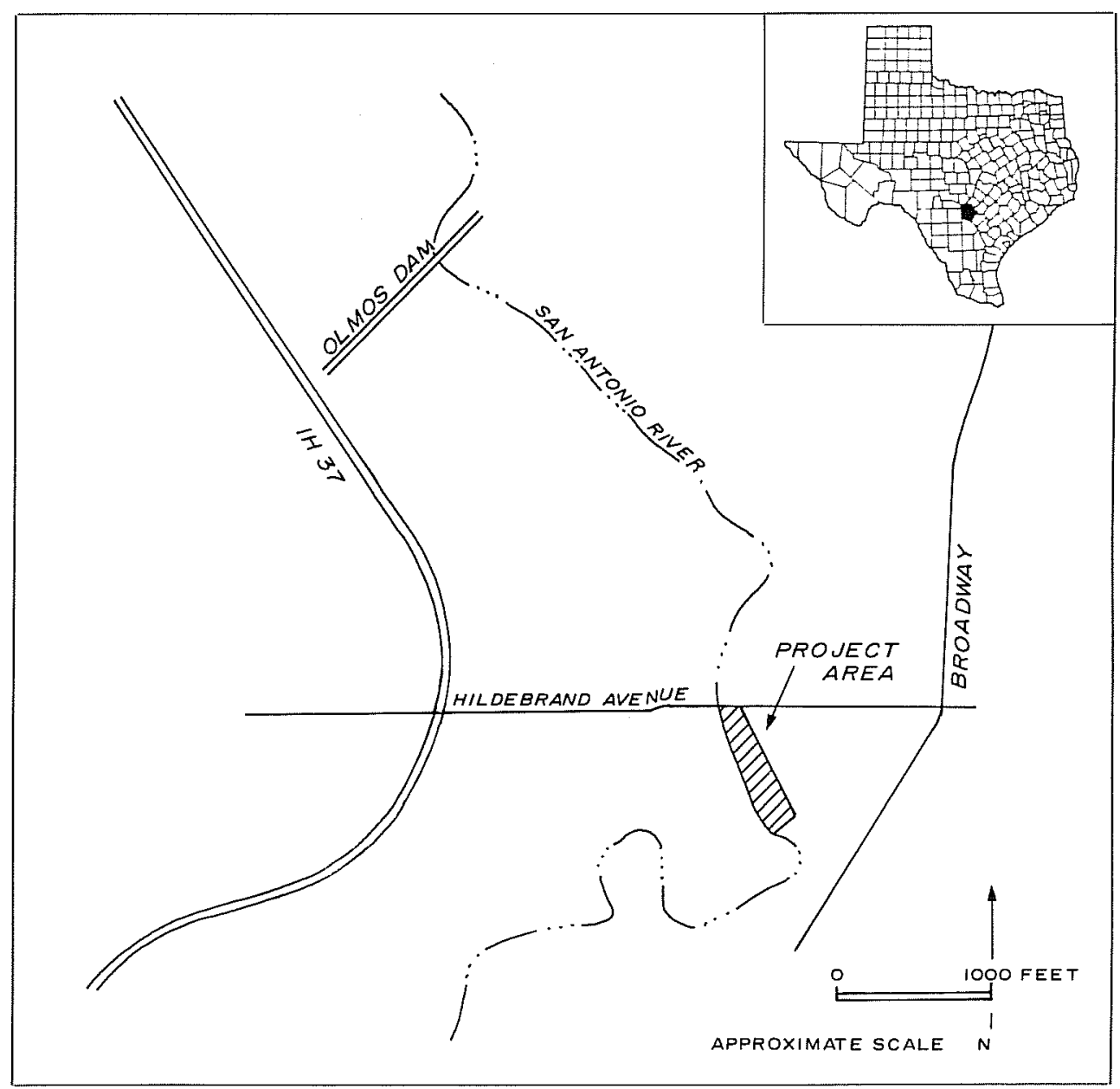

Figure 1. Project Location. 


\section{HISTORICAL BACKGROUND}

When considering the area below the source of the San Antonio River, it is not surprising that there is evidence of occupation from the earliest known peoples of central-south Texas, the Paleo-Indians. Their artifacts are known to be associated with radiocarbon dates between 9200 and 6000 B.C. The presence of a "populous ranchería of Indians" was recorded by Fray Antonio de Olivares in 1709 (Tous 1930a:5). A vivid description of the headwaters of the San Antonio River was presented by Fray Isidro Felix de Espinosa in 1716 (Tous 1930b:9-10):

... by an open path we arrived at the River San Antonio. This river is very desirable and favorable for its pleasantness, location, abundance of water, and a multitude of fish. It is surrounded by very tall nopals, poplars, elms, grapevines, black mulberry trees, laurels, strawberry vines and genuine fan-palms. There is a great deal of flax and wild hemp, an abundance of maiden-hair fern and many medicinal herbs. Merely in that part of the density of its grove which we penetrated seven streams of water meet. Those, together with others concealed by the brushwood, form at a little distance its copious waters, which are clear, crystal and sweet.

In 1718, the Presidio of San Antonio de Bejar and Mission San Antonio de Valero (the Alamo) were founded on the waters of San Pedro Creek. The mission was soon moved to the east bank of the San Antonio River, and an acequia, or irrigation ditch, was begun, drawing water from the river just to the south of Pioneer Park.

The springs at the headwaters of the river became a popular camping place for the military during the Republic period. Sheriff William Wilson of Galveston County established a camp there for his company in October 1839 during his campaign against the Comanche. In the summer of 1840 , the springs were the site of Camp Cooke (Pierce 1969:136-140).

During that same period, various individuals began to encroach upon the ejidos, or public lands, granted by the King of Spain to the Villa of San Fernando upon its founding. These lands included the headwaters of the river and the land below. The efforts of the city to evict these intruders resulted in a suit that was resolved by the Texas Supreme Court in 1851, finding in favor of the city (Texas Supreme Court Cases 1883:289-332). This freed the city to sell the land in order to construct a new jail and courthouse.

The lands were resurveyed and divided into lots in 1852. Two of these plots, lots 26 and 27, District 2 , Range 1 , were conveyed by the city to August Liecke in November 1852 and June 1853 (Fig. 2). The combined acreage totaled 26.81 acres and sold for $\$ 66$. Pioneer Park is the western edge of this tract. Liecke occupied the property, probably with a home on New Braunfels Street, the eastern boundary, and was grazing some 20 cattle. At that time Hildebrand Avenue, extending only from New Braunfels Street to the San Antonio River, was known as Cow Street (Probate Records Vol. 7:485). Upon Liecke's death, January 11, 1885, the property passed to his heirs, with the western portion granted to his daughters, Theresa Zuleme Jungbecker and Julia Heberer (DR Vol. 290:121). In 1917, they sold the property to Guillermo A. and Margarita Mecado de Alonso for a total price of $\$ 23,606.43$ ( $D R$ Vol. 544:28-30). At that time, Cow Street was known as Carey Avenue, and River Road (now Broadway) had been established through the middle of the property. In May 1921, Alonso and his wife sold the property to Doctor Aurgliano Urrutia for $\$ 30,000$ (DR Vol. 638:202).

Aurgliano Urrutia was born in Xochimilco, a village near Mexico City, June 6, 1872. His mother died in childbirth, and he grew up an orphan, working his way through school. Upon completion of high school, he earned a merit diploma signed by the president of Mexico, General Porfirio Díaz. He entered the military medical school and earned his medical degree in 1895 and was appointed professor of surgery. He later founded a private hospital, the Sanatoria Urrrutia, at Coyoacan, a suburb of Mexico City (Graham 1972).

In October 1912, he preformed cataract surgery on General Victoriano Huerta, a friend since the campaigns in Guererro in 1893 . While the general was convalescing, he was permanently relieved of his command by President Madero. In February 1913, Huerta overthrew Madero and became president of Mexico. The following April, Urrutia was appointed Secretary of Gobernación and Huerta's right-hand man. Since both were of Indian blood, they were often portrayed as Huitzilopochtli and Huichilobos, to whom the Aztecs offered human sacrifices (Meyer 1972:10,43,45,143). With the fall of Huerta's government in July 1914, Dr. Urrutia was ordered into exile. He established his residency in San Antonio in 1916, and in 1918 constructed his residence, Quinta Urrutia, in the 3200 block of Broadway. Modeled after his home in Mexico, it 


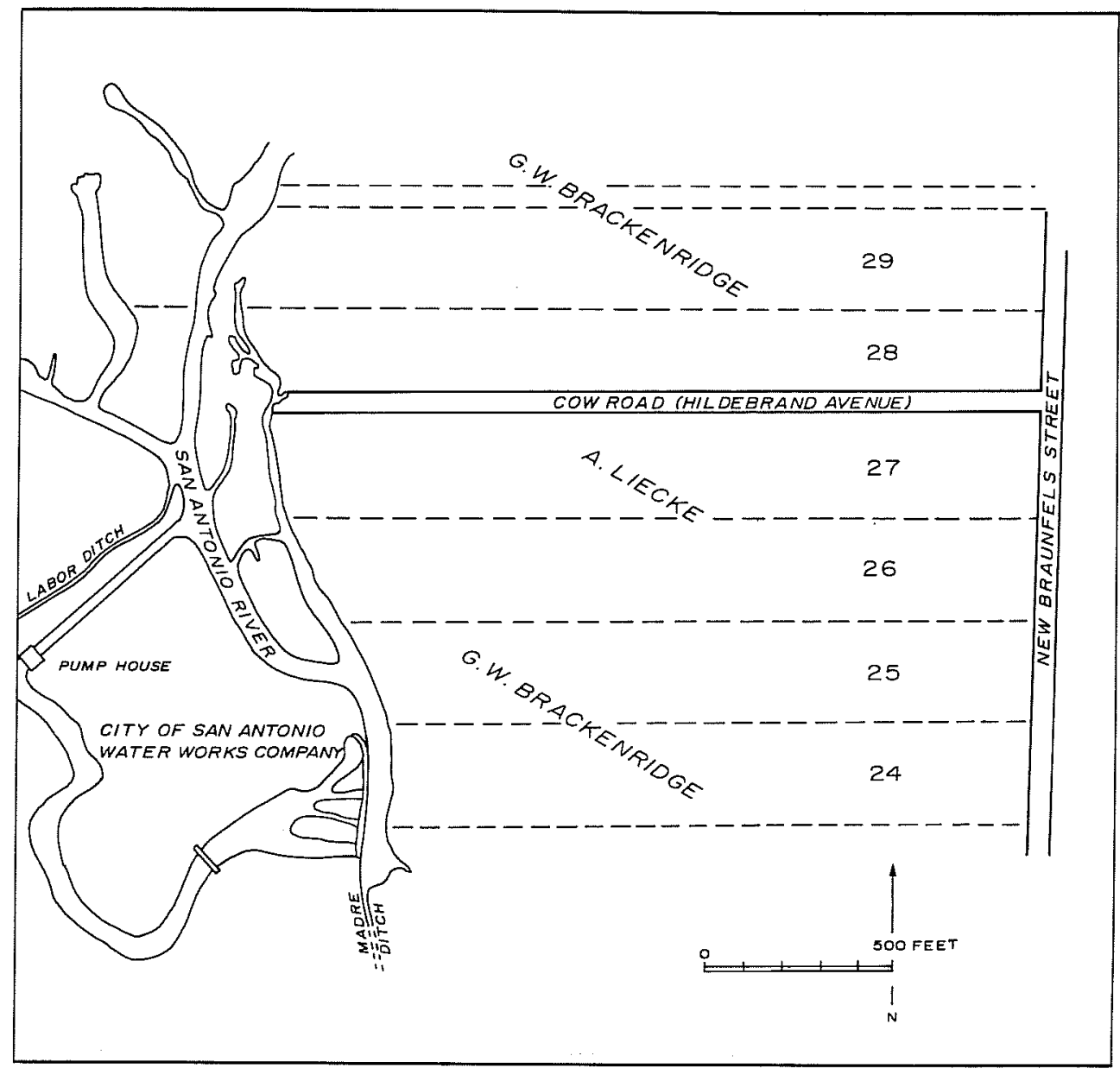

Figure 2. Property Division, ca. 1879.

stood as a unique landmark until it was demolished in 1962 (San Antonio News 1962a).

With his purchase of the Hildebrand Avenue and Broadway property, approximately one mile north of Quinta Urrutia, he established his summer home on the San Antonio River. In 1923, he constructed a home and servants quarters, surrounded by lavish fountains and statuary, which he called Miraflores. Pioneer Park currently occupies a portion of this property. Urrutia sold the property to USAA in May 1962 for $\$ 300,000$ (San Antonio Express 1962b).

Dr. Urrutia, a legendary sight in San Antonio, with his flowing black cape and slouch hat, was always the subject of mystery and myth, and the mention of his name, even today, brings forth a favorite tale from residents who knew him. $\mathrm{He}$ fathered 18 children by five wives, and died at the age of 104 in 1974 (Texas Monthly 1985).

\section{CONCLUSIONS}

The planned developments within Pioneer Park should have no impact on prehistoric or historic resources within the property. Since the work is to be concentrated along the edge of the river channel, the constant erosion and redeposition of silt would have eradicated any evidence of previous occupations. A review of numerous old maps and surveys indicates that the river channel has been in a constant state of change over the years, especially when the springs were flowing. However, should further alterations within the interior of the park be anticipated, where buried historical resources might be affected, monitoring should be considered. Since until recently there was an active spring on the property, the existence of buried materials relating to prehistoric occupation, as well as possible historic remains, cannot be discounted. 


\section{REFERENCES CITED}

Bexar County, Texas

Deed Records (DR)

Originals and microfilm located at the Bexar County Courthouse, San Antonio, Texas.

Probate Records

Originals and microfilm located at the Bexar County Courthouse, San Antonio, Texas.

Fox, A. A.

1975 An Archaeological Assessment of the Southern Portions of the Olmos Basin, Bexar County, Texas. Center for Archaeological Research, The University of Texas at San Antonio, Archaeological Survey Report 9.

Graham, B.

1972 Urrutia: Centenarian. San Antonio Express, June 4.

Katz, S. R. and A. A. Fox

1979 Archaeological and Historical Assessment of Brackenridge Park, City of San Antonio, Texas. Center for Archaeological Research, The University of Texas at San Antonio, Archaeological Survey Report 33.

Lukowski, P. D.

1988 Archaeological Investigations at $41 \mathrm{BX} 1$, Bexar County, Texas. Center for Archaeological Research, The University of Texas at San Antonio, Archaeological Survey Report 135.

Meyer, M. C.

1972 Huerta: A Political Portrait. University of Nebraska Press, Lincoln, Nebraska.

Orchard, C. D.

1966 Two Etcetera Lots in the Orchard Collection. Paper presented at the Texas Archeological Society Annual Meeting, San Antonio.

1974 The Olmos Basin. Manuscript on file at the Center for Archaeological Research, The University of Texas at San Antonio.
Orchard, C. D. and T. N. Campbell

1954 Evidences of Early Man from the Vicinity of San Antonio, Texas. The Texas Journal of Science 6(4):454-465.

Pierce, G. S.

1969 Texas Under Arms: The Camps, Post, Forts and Military Towns of the Republic of Texas. Encino Press, Austin.

San Antonio Express 1962a Urrutia Sells More Property, May 20.

1962b Dr. Urrutia Sells Property for $\$ 300,000$, May 29.

Stothert, K. E.

1989 The Archaeology and Early History of the Head of the San Antonio River. Southern Texas Archaeological Association, Special Publication 5, and Incarnate Word College Archaeology Series 3. San Antonio.

Texas Monthly

1985 A Tough Hombre, April:108-110, Austin.

Texas Supreme Court Cases

1883 Reports of Cases Argued and Decided in the Supreme Court of the State of Texas During the Austin Term, 1851 and a part of Galveston Term 1852. Vol. VII. Published by O. C. Hartley, Houston, Texas.

Tous, Rev. G.

1930a The Espinosa-Olivares-Aguirre Expedition of 1709. Preliminary Studies of the Texas Catholic Historical Society 1(3), March.

1930b Ramón Expedition: Espinosa's Diary of 1716. Preliminary Studies of the Texas Catholic Historical Society 1(4), April . 